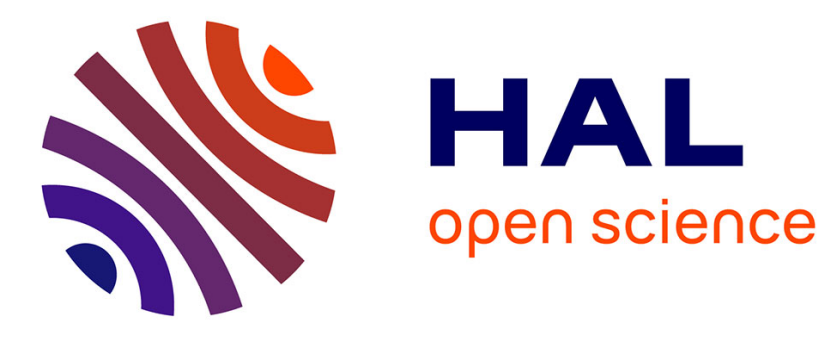

\title{
Cerebral quantitative DTI and tractography in 25 patients with PLP1-related disorders
}

\author{
Catherine Sarret, Jean-Jacques Lemaire, Anna Sontheimer, Jérôme Coste, \\ Bruno Pereira, Basile Roche, Odile Boespflug-Tanguy
}

\section{To cite this version:}

Catherine Sarret, Jean-Jacques Lemaire, Anna Sontheimer, Jérôme Coste, Bruno Pereira, et al.. Cerebral quantitative DTI and tractography in 25 patients with PLP1-related disorders. 12th European Paediatric Neurology Society Congress, European Paediatric Neurology Society (EPNS), Jun 2017, Lyon, France. pp.e76, 10.1016/j.ejpn.2017.04.1187 . hal-01654532

\section{HAL Id: hal-01654532 \\ https://hal.uca.fr/hal-01654532}

Submitted on 7 Nov 2018

HAL is a multi-disciplinary open access archive for the deposit and dissemination of scientific research documents, whether they are published or not. The documents may come from teaching and research institutions in France or abroad, or from public or private research centers.
L'archive ouverte pluridisciplinaire HAL, est destinée au dépôt et à la diffusion de documents scientifiques de niveau recherche, publiés ou non, émanant des établissements d'enseignement et de recherche français ou étrangers, des laboratoires publics ou privés. 


\title{
Cerebral quantitative DTI and tractography in 25 patients with PLP1-related disorders
}

\author{
C. Sarret (1), J.J. Lemaire, A. Sontheimer, J. Coste, B. Pereira, \\ B. Roche, O. Boespflug-Tanguy
}

1. Image-Guided Clinical Neuroscience and Connectomics (IGCNC), UMR6602, Institut Pascal, University Clermont Auvergne, Clermont-Ferrand, France

DOI: 10.1016/j.ejpn.2017.04.1187

\begin{abstract}
:
Objective: We used brain diffusion tensor imaging (DTI) and tractography to analyze the severity of patients with PLP1-related disorders (Pelizaeus- Merzbacher disease and spastic paraplegia type 2).
\end{abstract}

Methods: Twenty-five male patients (ranged from 0.7 to 43.5 years) with PLP1- related disorder were included in this DTI study. Subjects were classified according to best motor function acquired before 5 years into five categories (from PMD0 without motor acquisition to PMD4 with autonomous walking). We performed a quantitative DTI study on different brain regions of white or grey matter, tracking of the cortico-spinal fascicles (CSF) and whole brain tractography.

Results: No difference was observed between severity groups on quantitative DTI parameters (apparent diffusion coefficient, fractional anisotropy, radial and axial diffusivities) using two different DTI software. Tractography of the CSF did not reveal significant differences that could permit to distinguish severity groups. On the contrary, whole brain tractography seems to be a more relevant approach with high abnormalities in fibers from semi-oval centers and corpus callosum linked to clinical severity.

Conclusion: To distinguish early the clinical severity of patients with PLP- pathies is a present challenge to consider early therapeutical approaches in these disorders. Tractography of whole brain could be an interesting way of classifying patients and following disease's severity. 